\title{
ACE-inhibition is superior to endothelin A receptor blockade in preventing abnormal capillary supply and fibrosis of the heart in experimental diabetes
}

\author{
M.-L. Groß ${ }^{1}$ - N. Heiß ${ }^{1}$ - M. Weckbach ${ }^{1}$ A. Hansen ${ }^{2}$ A. El-Shakmak ${ }^{4}$ A. Szabo ${ }^{4} \cdot$ K. Münter ${ }^{5}$ E. Ritz E $^{3}$ \\ K. Amann6 \\ ${ }^{1}$ Department of Pathology, University of Heidelberg, Heidelberg, Germany \\ 2 Department of Cardiology, University of Heidelberg, Heidelberg, Germany \\ ${ }^{3}$ Department of Internal Medicine, Nephrological Section, University of Heidelberg, Heidelberg, Germany \\ ${ }^{4}$ Department of Pediatric Nephrology, Semmelweis University Budapest, Budapest, Hungary \\ ${ }^{5}$ Bayer AG, Wuppertal, Germany \\ ${ }^{6}$ Department of Pathology, University of Erlangen, Erlangen, Germany
}

\begin{abstract}
Aims/hypothesis. There is little information whether cardiac capillary supply is deranged in diabetes. Hyperglycaemia is a potent stimulus for endothelin-1 (ET-1) production. We therefore hypothesised that increased ET-1 production in Streptozotocin-induced Type 1 diabetes causes abnormalities of cardiac capillaries and the aorta. To this end we compared the effects of an ET receptor A blocker $\left(E^{-}-\mathrm{RB}\right)$ with that of an ACE-inhibitor (ACE-i) or their combination in rats with Streptozotocin (STZ) diabetes.

Methods. Sprague Dawley rats were injected with $65 \mathrm{mg} \mathrm{STZ}$ i.v. and subsequently developed diabetes. Rats were left untreated or received daily either the ACE-i Trandolapril, the $\mathrm{ET}_{\mathrm{A}}-\mathrm{RB}$ Darusentan or a combination of both. After 6 months the experiment was terminated and the heart and the aorta were investigated using quantitative morphological techniques.

Results. ACE-i but not $\mathrm{ET}_{\mathrm{A}}-\mathrm{RB}$ lowered blood pressure in STZ Type 1 diabetic rats. Capillary length density was lower in untreated STZ diabetic rats
\end{abstract}

$\left(2932 \pm 128 \mathrm{~mm} / \mathrm{mm}^{3}\right)$ compared to non-diabetic control rats $\left(3410 \pm 252 \mathrm{~mm} / \mathrm{mm}^{3}\right)$. Treatment with ACE- $\mathrm{i}$ $\left(3568 \pm 431 \mathrm{~mm} / \mathrm{mm}^{3}\right)$, but not with $E T_{A}-R B$ $\left(2893 \pm 192 \mathrm{~mm} / \mathrm{mm}^{3}\right)$, prevented the decrease in capillary supply. Volume density of the myocardial interstitium was higher in untreated STZ diabetic rats $(0.86 \pm 0.04 \%)$ compared to non-diabetic control rats $(0.36 \pm 0.06 \%)$. In all three intervention groups the values were lower (ACE-i: $0.53 \pm 0.05 \%, \mathrm{ET}_{\mathrm{A}}-\mathrm{RB}$ : $0.7 \pm 0.08 \%$ and combination: $0.69 \pm 0.1)$.

Conclusion/interpretation. Our study identifies a capillary defect of the heart in STZ diabetes, i.e. decreased capillary supply. This abnormality was reversed by ACE-i, but not by $\mathrm{ET}_{\mathrm{A}}-\mathrm{R}$ blockade. A similar trend, although not complete normalisation, was seen in cardiac fibrosis. [Diabetologia (2004) 47:316-324]

Keywords Diabetes mellitus - Animal model - Heart · Capillary · Fibrosis · Endothelin-1 - ACE-inhibitor · Endothelin A receptor blocker · Stereology ·

Hyperglycaemia
Received: 4 August 2003 / Revised: 22 October 2003

Published online: 15 January 2004

C) Springer-Verlag 2004

M.-L. Groß (®)

Department of Pathology, University of Heidelberg,

Im Neuenheimer Feld 220/221, 69120 Heidelberg, Germany

E-mail: Marie-Luise_Gross@med.uni-heidelberg.de

Abbreviations: ET-1, Endothelin1 - STZ, streptozotocin · ACE-i, ACE-inhibitor - $\mathrm{ET}_{\mathrm{A}} \mathrm{-RB}$, ET receptor A blocker . AT1, Ang II receptor type 1 blockers · SD, Sprague Dawley
Diabetes mellitus is associated with high cardiac mortality. The heart of diabetic patients has a number of abnormalities which go beyond the widely held notion of coronary heart disease from accelerated atherogenesis $[1,2]$. The spectrum of structural changes in so called "diabetic cardiomyopathy" [3] comprises, amongst others, left ventricular hypertrophy, cardiac interstitial fibrosis and metabolic abnormalities. Both the renin angiotensin system (RAS) and the endothelin system (ET) are thought to play a role in the pathogenesis of cardiac fibrosis and disturbed angiogenesis. In the heart ET-1 is produced by both cardiomyocytes 
and endothelial cells, and cardiomyocytes express high affinity ET-1 binding sites $[4,5,6]$. ET-1 induces contraction and increases inotropy of cardiomyocytes. It also regulates salt and water homeostasis through actions on the kidney, stimulates the RAS and sympathetic nerve systems, contracts vascular smooth muscle cells and induces hypertrophy of vascular smooth muscle cells, mesangial cells and cardiomyocytes $[7$, 8]. ET-1 also mediates, at least in part, the chronic effects of Ang II on blood pressure [9, 10]. Conversely, ACE-inhibitors (ACE-i) and Ang II receptor type 1 blockers (AT1) diminish ET-1 expression [11, 12, 13]. In theory these findings would provide a strong rationale for the combination of endothelin receptor blockers $\left(\mathrm{ET}_{\mathrm{A}}-\mathrm{RB}\right)$ with ACE-i or AT1 receptor blockers.

ET-1 is responsible for the maintenance of basal vasomotor tone. Plasma ET-1 concentrations are increased in diabetic patients [14] and STZ-injected rats [15]. Whether increased ET-1 concentrations play a role in the genesis of structural changes of the heart has not yet been investigated. Evidence of a beneficial effect of ET on blood pressure and the heart has been provided in non-diabetic models [16, 17, 18, 19, 20].

Our aim was to compare the effect of a specific ETA receptor antagonist with the well documented effects of an ACE-i (as well as the combination of both) on the structural lesion of the heart in an experimental model of Type 1 diabetes, with a particular focus on capillarisation, and volume of interstitial fibrous tissue.

\section{Methods}

Animals. Male Sprague Dawley rats (Charles River, Germany, mean body weight: $176 \pm 19.8 \mathrm{~g})$ were housed at constant room temperature $\left(21^{\circ} \mathrm{C}\right)$ and humidity $(75 \%)$ at a 12 -h light and $12-\mathrm{h}$ dark cycle. The rats had free access to water and standard rat pellets (Altromin 1324, Lage/Lippe, Germany). Experimental diabetes was induced by i.v. injection of $65 \mathrm{mg}$ Streptozotocin (STZ) (Sigma Aldrich Chemie, Deisenhofen, Germany). Hyperglycaemia developed 2 days after STZ administration. Thereafter, diabetic rats were treated daily with $4.1 \pm 1.4 \mathrm{IU} / \mathrm{kg}$ body weight (bw) of long acting human insulin (Insulin Ultratard HM, Aventis, Frankfurt, Main, Germany, 40 I.U./ml). We confirm, that we followed the 'Principles of Laboratory Animal Care'.

Experimental protocol. Four days after induction of diabetes the rats were randomly allocated to the following five experimental groups: (i) untreated non-diabetic control rats $(n=8)$, (ii) untreated diabetic rats $(n=10)$, (iii) diabetic rats + endothelin receptor blocker $\left(\mathrm{ET}_{\mathrm{A}}-\mathrm{RB}\right.$ ) (Darusentan, $50 \mathrm{mg} / \mathrm{kg}$ bw, $n=9$ ), (iv) diabetic rats + ACE-inhibitor (ACE-i) (Trandolapril, $0.3 \mathrm{mg} / \mathrm{kg}$ bw, $n=12)$, (v) diabetic rats $+\mathrm{ET}_{\mathrm{A}}-\mathrm{RB}+\mathrm{ACE}-\mathrm{i}$ in combination (with doses as above, $n=12$ ).

Medications were administered in the drinking fluid at concentrations calculated to deliver the above mentioned doses. The concentrations of drugs in the drinking fluid were adjusted accordingly. Daily food and water consumption were monitored. Body weight, blood glucose and blood pressure (by tail plethysmography) were measured at regular intervals. After 3 , 5 and 6 months the rats were kept in metabolic cages for a 24-h urine collection. Urinary albumin excretion was measured using a rat specific sandwich ELISA system as described in detail elsewhere [21].

After 6 months the experiment was terminated by retrograde aortic perfusion with glutaraldehyde for morphometric and stereological investigations or with ice cold $0.9 \% \mathrm{NaCl}$ for immunohistochemistry and in situ hybridisation, respectively [22]. Perfusion pressure was carefully monitored and adequacy of fixation was examined in pilot experiments.

Tissue preparation. After perfusion, the hearts of the rats were taken out to measure weight and volume. Tissue sampling and sectioning was done according to the orientator method: uniformly random sampling was achieved by preparing a set of equidistant slices of the left ventricle and the interventricular septum with a random start. Two slices were selected by area-weighted sampling and processed [22]. Eight pieces of the left ventricular wall, including the septum were embedded in Epon-Araldite. Semithin sections $(1 \mu \mathrm{m})$ were cut, stained with methylene-blue and basic fuchsin and were examined by light microscopy with oil immersion and phase contrast at a magnification of 1000:1. After embedding, semithin sections were prepared and stained as described elsewhere [21].

\section{Stereological analysis}

Quantitative stereology: heart. The length density $\left(\mathrm{L}_{\mathrm{v}}\right)$ of myocardial capillaries, i.e. the length of all capillaries per unit myocardial tissue volume, and the volume density $\left(\mathrm{V}_{\mathrm{v}}\right)$ of cardiac capillaries, defined as the volume of capillaries per unit myocardial tissue volume, were measured in eight systematically subsampled areas per section $\left(57,600 \mu \mathrm{m}^{2}\right)$ using the point-counting method and a Zeiss eyepiece with 100 points for point counting (Integrationsplatte II; Zeiss, Oberkochen, Germany) [21]. The length density of myocardial capillaries $\left(\mathrm{L}_{\mathrm{v}}\right)$ was determined by using the equation $\mathrm{L}_{\mathrm{v}}=2 \mathrm{Q}_{\mathrm{A}} \cdot \mathrm{Q}_{\mathrm{A}}$ is the area density (i.e. the number of capillary profiles per area of myocardial reference tissue) [21].

Volume density $\left(\mathrm{V}_{\mathrm{v}}\right)$ of interstitial tissue and myocytes was obtained using the point-counting method [21] according to the equation $\mathrm{P}_{\mathrm{p}}=\mathrm{V}_{\mathrm{v}}$. Intercapillary distance was calculated according to a modification of the formula by [23].

Wall thickness and lumen diameter of intramyocardial arteries (diameter: 20-200 $\mu \mathrm{m}$ [24, 25]) were determined planimetrically using a semiautomatic image analysing system (Videoplan, Kontron, Eching, Germany). Wall-to-lumen ratio was calculated by dividing wall thickness and lumen diameter as described in detail [21].

Morphology of the aorta ascendens. Wall thickness of the aorta was measured on semithin sections using planimetry, as described in detail elsewhere [21].

\section{Immunohistology}

Paraffin sections were prepared and were reacted with the following antibodies using the avidin biotin method: Collagen IV $(\alpha$-Collagen IV, polyclonal rabbit, Bio Trend, Cologne, Germany, 1:25) and ET-A receptor (sheep ETRA, Bio Trend Köln; 1:50) were investigated. We chose the ET-A receptor, because this receptor is predominantly found in the heart of rats [26]. ET- 1 and TGF- $\beta$ influence each other, therefore the expression of TGF- $\beta$ (TGF- $\beta 1$ poyclonal rabbit, Santa Cruz, Calif., USA) was analysed. 
Table 1. Animal data

\begin{tabular}{|c|c|c|c|c|c|c|}
\hline Animal group & $\begin{array}{l}\text { Non-diabetic } \\
\text { control }(n=8)\end{array}$ & $\begin{array}{l}\text { Untreated } \\
\text { diabetes } \\
(n=10)\end{array}$ & $\begin{array}{l}\text { Diabetes + } \\
\mathrm{ET}_{\mathrm{A}}-\mathrm{RB}(n=9)\end{array}$ & $\begin{array}{l}\text { Diabetes }+ \\
\text { ACE-i }(n=12)\end{array}$ & $\begin{array}{l}\text { Diabetes }+ \\
\text { combination } \\
(n=12)\end{array}$ & ANOVA \\
\hline $\begin{array}{l}\text { Left ventricular weight/body } \\
\text { weight ratio }(\mathrm{mg} / \mathrm{g})\end{array}$ & $2.15 \pm 0.18^{b}$ & $4.06 \pm 0.24^{\mathrm{a}}$ & $3.72 \pm 0.22^{\mathrm{a}, \mathrm{b}}$ & $3.41 \pm 0.29^{\mathrm{a}, \mathrm{b}}$ & $3.78 \pm 0.42^{a}$ & $p<0.05$ \\
\hline $\begin{array}{l}\text { Left ventricular/total } \\
\text { heart weight ratio }\end{array}$ & $0.71 \pm 0.06$ & $0.68 \pm 0.06$ & $0.7 \pm 0.05$ & $0.67 \pm 0.07$ & $0.69 \pm 0.05$ & NS \\
\hline $\mathrm{HbA}_{1 \mathrm{c}}(\%)$ & $5 \pm 0.2$ & $9.7 \pm 0.5^{\mathrm{a}}$ & $9.4 \pm 1.3^{\mathrm{a}}$ & $9.2 \pm 1.2^{\mathrm{a}}$ & $9.8 \pm 1.2^{\mathrm{a}}$ & $p<0.05$ \\
\hline Daily food consumption (g) & $37 \pm 3$ & $58 \pm 6^{\mathrm{a}}$ & $50 \pm 8^{a}$ & $47 \pm 3^{a}$ & $51 \pm 9^{a}$ & $p<0.05$ \\
\hline Systolic bp $(\mathrm{mmHg})$ & $114 \pm 13$ & $173 \pm 13^{a}$ & $154 \pm 16^{b}$ & $137 \pm 14^{b}$ & $133 \pm 18^{b}$ & $p<0.05$ \\
\hline Albuminuria (mg/24 h) & $0.48 \pm 0.15$ & $1.73 \pm 0.56^{\mathrm{a}}$ & $1.06 \pm 0.38$ & $0.68 \pm 0.11^{b}$ & $0.56 \pm 0.15^{b}$ & $p<0.05$ \\
\hline
\end{tabular}

Data are given as mean $\pm \mathrm{SD}$

${ }^{\mathrm{a}} p<0.05$ vs non-diabetic control, ${ }^{\mathrm{b}} p<0.05$ vs untreated diabetes

Cryostat sections that were $5 \mu \mathrm{m}$ thick were prepared and were reacted with the following antibodies using the avidin biotin method [10]: Collagen I ( $\alpha$-Collagen I, polyclonal rabbit, Chemicon, Tenecula, Calif., USA, 1:2000) and ET-1 $(\alpha-E T-1$ polyclonal rabbit, Biotrend, Cologne, Germany, $1: 50)$. The concentration that was optimal for staining was evaluated testing different dilution series in a pilot study. Two investigators who were blinded with regard to the animal group did semiquantitative scoring as described in detail [22].

Semiquantitative RT-PCR for cardiac ET-1 and TGF- $\beta$ mRNA expression

Total RNA $(1 \mu \mathrm{g})$ was dissolved in $20 \mu \mathrm{l}$ of a reaction mixture containing $4 \mathrm{mmol} / \mathrm{l} \mathrm{dATP}$, dCTP, dTTP, and dGTP; $10 \mathrm{U}$ RNAsin (Life Technologies BLR, Grand Island, N.Y., USA); 100 pmol random hexamers (Boehringer Mannheim, Mannheim, Germany); PCR buffer (final concentrations: $1.6 \mathrm{mmol} / \mathrm{l} \quad\left(\mathrm{NH}_{4}\right)_{2} \mathrm{SO}_{4}, 2.0 \mathrm{mmol} / \mathrm{l}$ Tris- $\mathrm{HCl} \quad[\mathrm{pH} \quad 8.4]$, $1.5 \mathrm{mmol} / \mathrm{M} \mathrm{MgCl} 2$ ); and $100 \mathrm{U}$ Superscript reverse transcriptase (Life Technologies BLR). After incubation at $42^{\circ} \mathrm{C}$ for $45 \mathrm{~min}$, the enzyme was denatured for $5 \mathrm{~min}$ at $94^{\circ} \mathrm{C}$. Semiquantification of ET- 1 and TGF- $\beta$ mRNA was carried out using deletion mutants of the ET- 1 and TGF- $\beta$ cDNA as internal standard. The amplifications of the mutants resulted in PCR products of $300 \mathrm{bp}$ for ET- 1 and $302 \mathrm{bp}$ for the TGF- $\beta$. The mutant cDNAs were added to the PCR mixture. Endogenous ET-1 $0.4 \mathrm{pg}$ or TGF- $\beta 0.05 \mathrm{pg}$ of plasmid respectively was added to the PCR mixture per sample. The PCR products were separated in a $3 \%$ metaphorgel and scanned as TIF data. The quotient of measured endogenous sample and aquivalent mutant was calculated by Scion-Image-program (National Institutes of Health, Bethesda, Md., USA).

In situ hybridisation for localisation of cardiac ET-1 and TGF- $\beta$ mRNA expression

Because plasma ET-1 concentrations are increased in diabetes and antagonism of the ET system might be effective, mRNA expression of ET- 1 was measured. ET- 1 and TGF- $\beta$ influence each other, subsequently mRNA expression of TGF- $\beta$ was measured also. For in situ hybridisation, transversal cryostat section of the myocardium $(10 \mu \mathrm{m})$ were used. Probe preparation, labelling, hybridisation and development were carried out as described in detail elsewhere [22].

\section{Statistics}

All data are expressed as means \pm SD. Kruskal-Wallis test and ANOVA, respectively, were chosen for analysis of variance, followed by the least-significant difference test to assess the differences between the groups. Results were considered significant if the $p$ value was less than 0.05 .

\section{Results}

Animal data. Untreated diabetic rats had stable, moderate hyperglycaemia throughout the 6 months of the study with a mean blood glucose concentration of $36.1 \pm 5.8 \mathrm{mmol} / \mathrm{l}$ and a mean $\mathrm{HbA}_{1 \mathrm{c}}$ of $9.7 \pm 0.5 \%$. Blood glucose concentrations were not modified by either ACE-i or $\mathrm{ET}_{\mathrm{A}} \mathrm{-RB}$ treatment. Despite higher food intake $(58 \pm 6 \mathrm{~g} /$ day $)$ in diabetic compared to nondiabetic rats ( $37 \pm 3 \mathrm{~g} /$ day), body weight was lower in untreated diabetic rats. Body weight, as well as food or water intake were not modified by treatment with ACE-i or $\mathrm{ET}_{\mathrm{A}}-\mathrm{RB}$ or both combined (Table 1).

The relative weight of the left ventricle, i.e. left ventricular weight/body weight ratio, was higher in all diabetic groups compared to non-diabetic rats $(p<0.05)$. It was lower $(p<0.05)$, but not normalised, when diabetic rats were treated with the $\mathrm{ET}_{\mathrm{A}}-\mathrm{RB}$ and the ACE-i. Serum cholesterol and LDL cholesterol concentrations were not significantly $(p<0.05)$ different between the experimental groups. Serum triglyceride concentrations were significantly higher in untreated diabetic rats $(4.2 \pm 0.17 \mathrm{mmol} / \mathrm{l})$ than in non-diabetic controls $(1.06 \pm 0.35 \mathrm{mmol} / \mathrm{l})$ and in treated diabetic rats $\left(2.5 \pm 1.65 \mathrm{mmol} / \mathrm{l} \mathrm{ET}_{\mathrm{A}}-\mathrm{RB}, 1.8 \pm 1.12 \mathrm{mmol} / \mathrm{l}\right.$ ACE-i and $1.4 \pm 0.7 \mathrm{mmol} / \mathrm{l}$ combination).

After 6 months of diabetes, systolic blood pressure (bp) was higher in untreated diabetic rats compared to 
Table 2. Stereological analysis of the heart

\begin{tabular}{|c|c|c|c|c|c|c|}
\hline Animal group & $\begin{array}{l}\text { Non-diabetic } \\
\text { control } \\
(n=8)\end{array}$ & $\begin{array}{l}\text { Untreated } \\
\text { diabetes } \\
(n=10)\end{array}$ & $\begin{array}{l}\text { Diabetes }+ \\
\operatorname{ET}_{\mathrm{A}}-\mathrm{RB}(n=9)\end{array}$ & $\begin{array}{l}\text { Diabetes }+ \\
\text { ACE-i }(n=12)\end{array}$ & $\begin{array}{l}\text { Diabetes }+ \\
\text { combination } \\
(n=12)\end{array}$ & ANOVA \\
\hline Mean intercapillary distance $(\mu \mathrm{m})$ & $17.8 \pm 0.5^{b}$ & $20.2 \pm 0.5^{\mathrm{a}}$ & $20.1 \pm 0.6^{\mathrm{a}, \mathrm{c}}$ & $17.3 \pm 0.6^{\mathrm{b}}$ & $18.3 \pm 0,9^{b}$ & $p<0.05$ \\
\hline $\mathrm{V}_{\mathrm{v}}$ interstitium $(\%)$ & $0.36 \pm 0.06^{b}$ & $0.86 \pm 0.04^{\mathrm{a}}$ & $0.70 \pm 0.08^{\mathrm{a}, \mathrm{b}, \mathrm{c}}$ & $0.53 \pm 0.05^{\mathrm{a}, \mathrm{b}}$ & $0.69 \pm 0.10^{\mathrm{a}, \mathrm{b}}$ & $p<0.05$ \\
\hline
\end{tabular}

Data are given as mean $\pm \mathrm{SD}$

${ }^{\mathrm{a}} p<0.05$ vs non-diabetic control, ${ }^{\mathrm{b}} p<0.05 \mathrm{vs}$. untreated diabetes, ${ }^{\mathrm{c}} p<0.05 \mathrm{ET}_{\mathrm{A}}-\mathrm{RB}$ treated diabetic rats vs. ACE-i treated rats $\mathrm{L}_{\mathrm{v}}$ : length density, $\mathrm{V}_{\mathrm{v}}$ : volume density

non-diabetic control rats; it was lower in rats treated with ACE-i and with the combination. In diabetic rats treated with the $\mathrm{ET}_{\mathrm{A}}-\mathrm{RB}$ bp ranged between untreated and ACE-i treated diabetic rats, but was still significantly $(p<0.05)$ lower than in untreated diabetic control rats.

Urinary albumin excretion as an index of renal dysfunction was higher in untreated diabetic than in nondiabetic rats $(p<0.05)$. Urinary albumin excretion was reduced and nearly normalised by ACE-i and combination treatment, but not by $\mathrm{ET}_{\mathrm{A}}-\mathrm{RB}$ treatment.

Quantitiative morphology of the myocardium (Fig. 1). Capillary length density was lower and mean intercapillary distance higher in untreated diabetic compared to non-diabetic control rats. Only ACE-i administered as mono therapy or in combination, but not $\mathrm{ET}_{\mathrm{A}}-\mathrm{RB}$, prevented the abnormality of myocardial capillary supply in diabetes (Table 2, Fig. 1).

The volume density of the interstitial tissue was increased in untreated diabetic compared to control rats and treated diabetic rats indicating cardiac fibrosis. Again, the treatment with the ACE-i was associated with the most marked prevention of the increase in interstitial tissue.

Quantitiative morphology of intramyocardial arterioles and of the aorta. The lumen diameter of intramyocardial arterioles was increased in untreated diabetic rats compared to non-diabetic control rats $(p<0.05)$. Only ACE-i treatment alone or in combination prevented such arteriolar enlargement, but not $\mathrm{ET}_{\mathrm{A}}-\mathrm{RB}$. Wall thickness of intramyocardial arterioles was increased in diabetic compared to control rats. It was lower in all intervention groups, but ACE-i in mono therapy or in combination, was more effective than $\mathrm{ET}_{\mathrm{A}}-\mathrm{RB}$. This was also true for the changes in walllumen ratio which went in parallel (Table 3 ).

The wall thickness of the aorta was increased in untreated diabetic rats compared to non-diabetic control rats and all treated diabetic rats $(p<0.05)$. The lumen diameter of the aorta was decreased in diabetic rats compared to control rats. Intervention with ACE-i mono therapy only significantly $(p<0.05)$ improved data.
Immunohistochemical investigations. Cardiac capillary and myocyte ET-1 protein expression by semiquantitative scoring was significantly $(p<0.05)$ higher in untreated diabetic rats $(0.8 \pm 0.2)$ compared to nondiabetic control rats $(0.2 \pm 0.2)$. Only combination treatment reduced ET-1 protein expression $(0.4 \pm 0.1$; $p<0.05)$, but not $\mathrm{ET}_{\mathrm{A}}-\mathrm{RB}(0.7 \pm 0.2)$ or $\mathrm{ACE}-\mathrm{i}$ treatment $(0.6 \pm 0.3)$.

ET-A receptor protein expression by semiquantitative scoring was higher $(p<0.05)$ in capillary endothelial cells and myocytes of untreated diabetic rats $(2.0 \pm 0.3)$ compared to non-diabetic control rats $(0.5 \pm 0.3)$. In diabetic rats ET-A receptor expression was lower $(p<0.05)$ after ACE-i $(1.4 \pm 0.3)$ or combination treatment $(1.3 \pm 0.3)$, but not $\mathrm{ET}_{\mathrm{A}}-\mathrm{RB}$ treatment $(1.8 \pm 0.4)$.

TGF- $\beta$ protein expression was significantly higher $(p<0.05)$ in untreated diabetic $(1.3 \pm 0.4)$ and $\mathrm{ET}_{\mathrm{A}}-\mathrm{RB}$ $(1.3 \pm 0.3)$ treated rats compared to decreased expression in non-diabetic control $(0.5 \pm 0.3)$, ACE-i treated $(0.5 \pm 0.3)$ and combination treated diabetic rats $(0.6 \pm 0.1)$.

Collagen IV protein expression was higher $(p<0.05)$ in untreated diabetic $(1.01 \pm 0.5)$ compared to non-diabetic rats $(0.07 \pm 0.01)$. All interventions reduced expression for collagen IV, but ACE-i and combination treatment were more effective (diabetes +

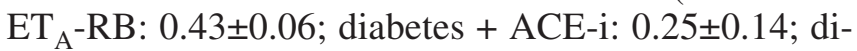
abetes + combination: $0.19 \pm 0.01)$.

Collagen I protein expression was not significantly $(p<0.05)$ different between experimental groups.

Semiquantitative RT-PCR for cardiac ET- 1 and TGF- $\beta$ mRNA expression. Relative ET-1 mRNA expression was increased $(p<0.05)$ in the heart of untreated diabetes compared to non-diabetic control rats. Cardiac ET1 mRNA expression was lower $(p<0.05)$ in diabetic rats on combination treatment, but not in ACE-i and $\mathrm{ET}_{\mathrm{A}}-\mathrm{RB}$ treated diabetic rats (Fig. 2).

In parallel, cardiac TGF- $\beta$ mRNA was higher $(p<0.05)$ in untreated diabetic rats compared to nondiabetic control rats. All interventions led to statistically significant lower TGF- $\beta$ mRNA levels, but they were normalised only in the combination group. 

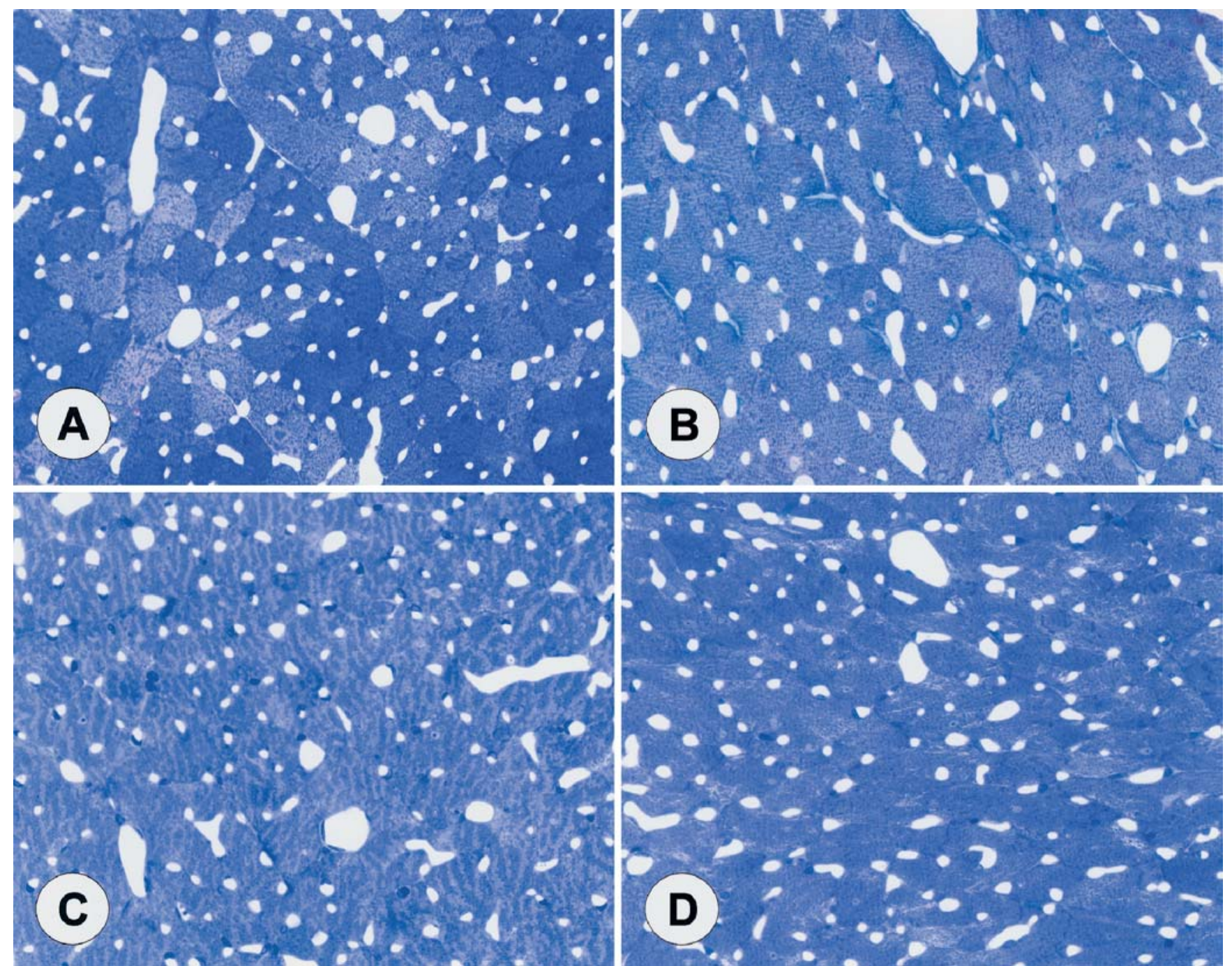

Fig. 1a-d. Normal capillary supply in a non-diabetic SD rat (a). Reduced density of capillary profiles and expansion of the nonvascular interstitium is clearly visible in the myocardium of an untreated diabetic rat (b). Myocardium of diabetic rats

treated with $\mathrm{ET}_{\mathrm{A}}-\mathrm{RB}(\mathbf{c})$ or combination treatment $(\mathbf{d})$ with almost normal myocardial capillary density. Semithin sections, mag.: 1:1200

Table 3. Measurements of intramyocardial arterioles and of the aorta thoracica descendens

\begin{tabular}{|c|c|c|c|c|c|c|}
\hline Animal group & $\begin{array}{l}\text { Non-diabetic } \\
\text { control }(n=8)\end{array}$ & $\begin{array}{l}\text { Untreated } \\
\text { diabetes } \\
(n=10)\end{array}$ & $\begin{array}{l}\text { Diabetes + } \\
\mathrm{ET}_{\mathrm{A}}-\mathrm{RB} \\
(n=9)\end{array}$ & $\begin{array}{l}\text { Diabetes }+ \\
\text { ACE-i }(n=12)\end{array}$ & $\begin{array}{l}\text { Diabetes + } \\
\text { combination } \\
(\mathrm{n}=12)\end{array}$ & ANOVA \\
\hline $\begin{array}{l}\text { Lumen diameter } \\
\text { of Intramyocardial arteries }(\mu \mathrm{m})\end{array}$ & $34.0 \pm 3.37 \mathrm{~b}$ & $39.9 \pm 5.30^{\mathrm{a}}$ & $38.1 \pm 5.25^{\mathrm{a}}$ & $37.1 \pm 5.15^{\mathrm{a}, \mathrm{b}}$ & $37.7 \pm 4.3^{b}$ & $p<0.05$ \\
\hline Wall thickness of the aorta $(\mu \mathrm{m})$ & $93.8 \pm 7.25^{\mathrm{b}}$ & $104 \pm 6.82^{a}$ & $93.8 \pm 6.32^{b}$ & $87.2 \pm 5.09 \mathrm{~b}$ & $92.5 \pm 12.06^{b}$ & $p<0.05$ \\
\hline Lumen diameter of the aorta $(\mu \mathrm{m})$ & $1319 \pm 199 \mathrm{~b}$ & $1045 \pm 114^{\mathrm{a}}$ & $1031 \pm 40^{\mathrm{a}, \mathrm{c}}$ & $1304 \pm 104^{b}$ & $983 \pm 176^{\mathrm{a}, \mathrm{b}}$ & $p<0.05$ \\
\hline Wall-to-lumen ratio aorta $\left(\times 10^{-3}\right)$ & $7.63 \pm 1.15^{b}$ & $10.9 \pm 2.06^{\mathrm{a}}$ & $7.53 \pm 0.85^{b}$ & $6.90 \pm 0.78^{b}$ & $9.4 \pm 3.37 \mathrm{a}$ & $p<0.05$ \\
\hline
\end{tabular}

Data are given as mean $\pm \mathrm{SD}$

${ }^{\mathrm{a}} p<0.05$ vs non-diabetic control, ${ }^{\mathrm{b}} p<0.05$ vs untreated diabetes, ${ }^{\mathrm{c}} p<0.05 \mathrm{ET}_{\mathrm{A}}-\mathrm{RB}$ treated diabetic rats vs ACE-i treated 
In situ hybridisation (Fig. 3). ET-1 mRNA expression of interstitial and capillary endothelial cells (Fig. 3) was increased $(p<0.05)$ in the heart of untreated diabetic rats compared to non-diabetic control rats. Neither treat- ment with ACE-i nor with $\mathrm{ET}_{\mathrm{A}}-\mathrm{RB}$ or the combination lowered ET-1 gene expression. TGF- $\beta$ mRNA expression of interstitial cells was increased $(p<0.05)$ in diabetic rats. All interventions lowered the expression.

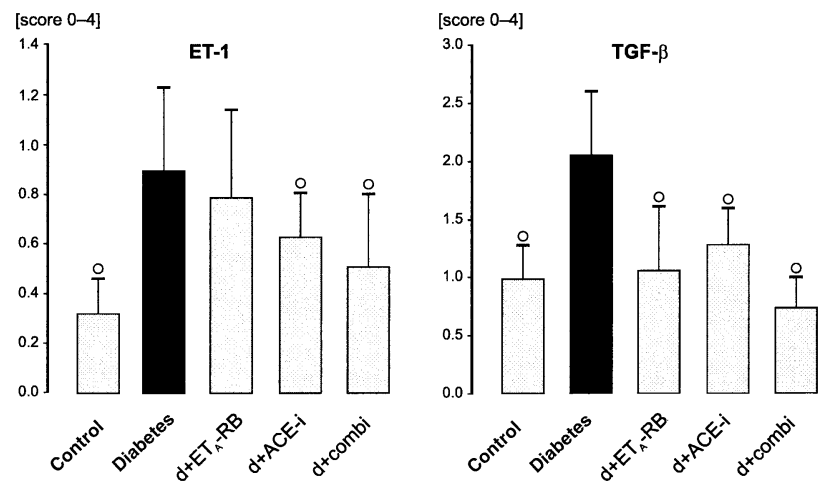

Fig. 2. Effect of $\mathrm{ET}_{\mathrm{A}}-\mathrm{RB}$ and ACE-i on expression of ET-1 and TGF- $\beta$ mRNA by semiquantitative RT-PCR

\section{Discussion}

Our study identifies decreased capillary supply as well as increased mean intercapillary distance as a new finding and confirmed marked interstitial fibrosis in the heart in experimental Type 1 STZ-induced diabetes. As to the pathomechanisms involved, it is of interest that the expression of collagen IV, ET-1 and TGF$\beta$ was increased in untreated STZ diabetic rats. Treatment with an ACE-i, but not with $\mathrm{ET}_{\mathrm{A}}-\mathrm{RB}$, abrogated both the capillary abnormality and the interstitial fibrosis. Combination of $\mathrm{ACE}-\mathrm{i}$ and $\mathrm{ET}_{\mathrm{A}}-\mathrm{RB}$ had no additive beneficial effect.

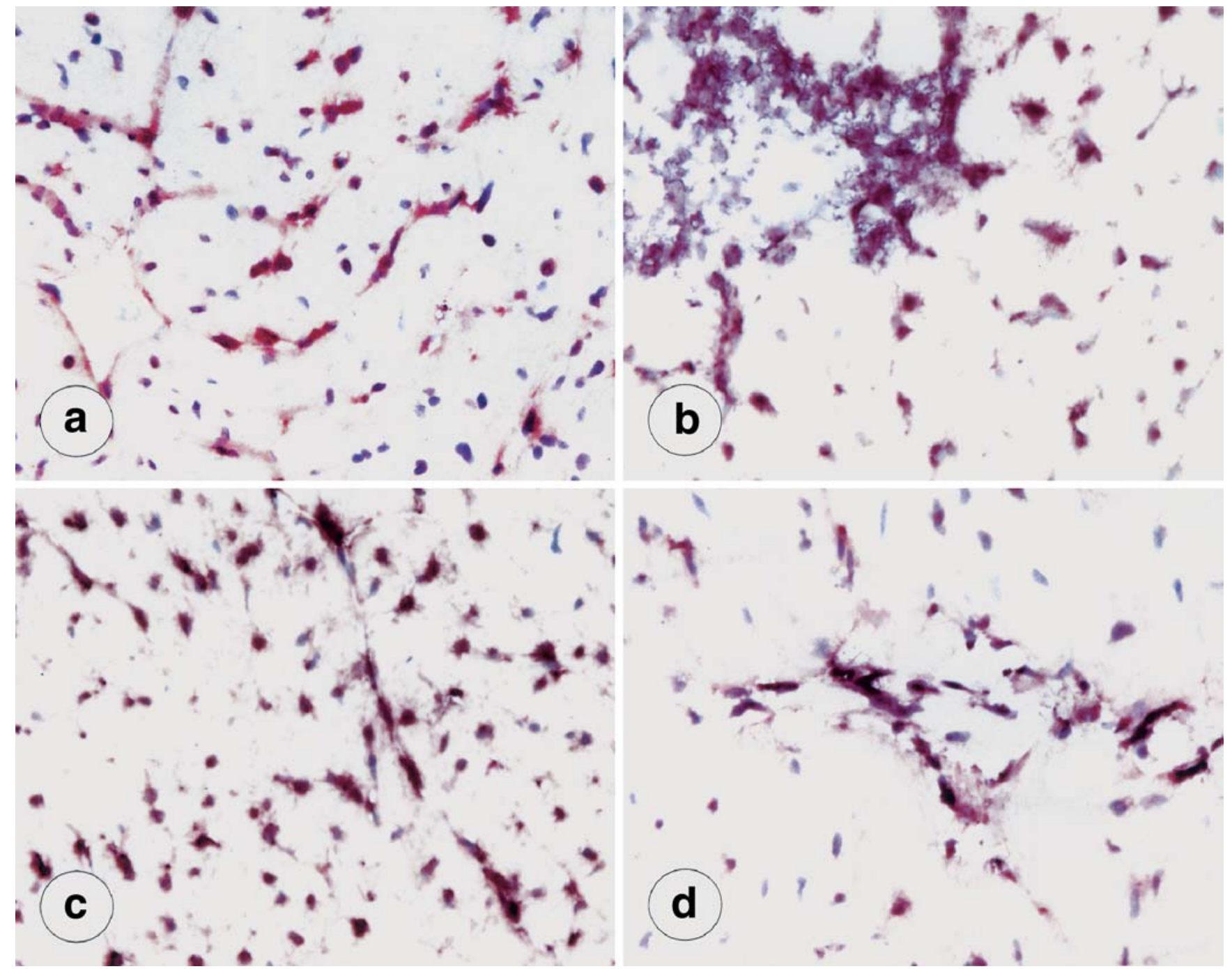

Fig. 3a-d. Expression of ET mRNA (brown signal) by non radioactive in situ hybridisation (magnification 1:400). Only moderate expression in the heart of an untreated non-diabetic control rat (a), in comparison to a marked increase in an un-

treated diabetic rat (b). Intervention with $\mathrm{ET}_{\mathrm{A}}-\mathrm{RB}$ monotherapy (c) and combination treatment with $\mathrm{ET}_{\mathrm{A}}-\mathrm{RB}$ and $\mathrm{ACE}-\mathrm{i}$ (d) lowered ET mRNA expression in diabetes 
The finding of diminished capillary-length density reflects the failure of the capillary growth and the failure to increase pari passu with the increase of cardiomyocyte volume, creating capillary/cardiomyocyte mismatch. The increased mean intercapillary distance implies that the distance from the centre of the capillaries to the centre of the cardiomyocyte, and by implication for oxygen diffusion, is increased. Although the study does not provide direct evidence, it seems logical that diminished capillary supply is at least one major cause contributing to the impaired ischaemia tolerance of the heart in diabetes.

We also confirmed previous findings of interstitial fibrosis i.e. non-replacement type of fibrosis. In the replacement type of fibrosis, fibrous tissue substitutes for vanished necrotic parenchyma. In contrast, the type of fibrosis we documented in the STZ diabetic heart constitutes primary fibrosis resulting from activation of interstitial fibroblasts, similar to what has been documented in rats exposed to aldosterone [27] or Ang II [28]. Cardiac fibrosis impairs left ventricular compliance, causes an abnormal stress relationship and (particularly in conjunction with diminished blood supply) interferes with the electrical stability of the heart [29].

As to the pathomechanisms involved, we found increased expression of ET-1, ET receptor, TGF- $\beta$ and collagen IV in untreated STZ diabetic rats, confirming, at least in part, data of other laboratories [30, 31, 32]. A further finding of potential pathogenetic relevance was increased systolic blood pressure measured by tail plethysmography.

The influence of $\mathrm{ET}_{\mathrm{A}}-\mathrm{RB}$ on bp is controversial, but several confounders make the comparison of the reported data difficult e.g. different administered doses, differences in animal models used and differences in bp measurement techniques [33, 34, 35]. Of note, $\mathrm{ET}_{\mathrm{A}}-\mathrm{RB}$ lowered bp in diabetic rats in our study. The maximal decrease in bp was seen with combination treatment. The increase in systolic bp in diabetes mellitus could be related to the stimulatory effect of hyperglycaemia on the RAS $[36,37,38]$ or generation of oxygen radical species reducing the availability of nitric oxide [39]. A normalisation of systemic bp in nonselective ET-1 blockade in diabetic rats is described [40]. At the same dose of Darusentan, no bp lowering was noted in rats with surgical ablation of the kidney $[19,41]$ further suggesting that the role of ET is specific for diabetes. A small but sustained reduction of 24-h blood pressure with Darusentan was noted, whereas endothelin-dependent vasorelaxation remained unchanged [42].

Using a two dimensional approach a significant increase of cardiac capillaries in STZ rats after $\mathrm{ET}_{\mathrm{A}}-\mathrm{RB}$ treatment is noted [33]. This finding is in contrast to our results using a stereological technique permitting analysis in three dimensional space. The above results using conventional methodology could easily have been flawed, however, by the anisotropy of cardiac tissue.

The ET receptor antagonist abrogated dysfunction of cultured endothelial cells exposed to high glucose concentrations [43]. It also has been shown that ET-1 mRNA receptor binding is increased in the hearts of diabetic rats [5, 44], similar to what is found in cardiac disease [13]. In the present long-term study increased ET-1 and ETA receptor expression could also be demonstrated in diabetic rats. ET-1 expression was decreased only by combination therapy. In contrast, increased expression of ET-A receptor was also reduced by ACE-i (and combination) therapy, but not by $\mathrm{ET}_{\mathrm{A}}-\mathrm{RB}$. This observation suggests a major role of the RAS in the up-regulation of the ET system in the heart of diabetic rats. Data reported in the literature are consistent with a high vascular ACE activity, which could be an important factor for the progressive deterioration of vascular function in STZ rats [45].

It is not clear why the $\mathrm{ET}_{\mathrm{A}}-\mathrm{RB}$ was less effective to prevent capillary deficit in the heart, although the ET1 system is up-regulated in diabetes. One explanation proposed by some authors is that damaged cardiomyocytes are unable to synthesise ET-1 in response to Ang II stimulation [13, 39, 46]. For diabetes this explanation is excluded by our results. We cannot exclude, however, post receptor abnormalities in diabetes, so that ETA receptor stimulation fails to yield an appropriate response. It has been speculated that an activated local RAS is responsible for an increased AT 2 receptor mediated response to ANG II in cardiomyocytes and subsequent apoptosis [46]. This hypothesis could explain the superior efficacy of the ACE-i in our study. Interestingly, in diabetes apoptosis of cardiomyocytes seem to occur independent of hypertension [39].

We found that $\mathrm{ET}_{\mathrm{A}}-\mathrm{RB}$ lowered cardiac interstitial fibrosis and wall thickness of the aorta. The volume density of the interstitium was lower in all intervention groups. $\mathrm{ACE}-\mathrm{i}$, but not $\mathrm{ET}_{\mathrm{A}}-\mathrm{RB}$ prevented the increase in wall thickness of intramyocardial arteries. However, the wall-to-lumen ratio of intramyocaradial arteries was also reduced by $\mathrm{ET}_{\mathrm{A}}-\mathrm{RB}$ compared to non-diabetic rats. The increase in aortic wall thickness was prevented by $\mathrm{ET}_{\mathrm{A}^{-}} \mathrm{RB}$ and $\mathrm{ACE}-\mathrm{i}$ suggesting a role for endogenous ET in the pathogenesis of vessel disease in diabetes. Additionally, $\mathrm{ET}_{\mathrm{A}}-\mathrm{RB}$ prevented $\mathrm{bp}$ increase and vascular remodelling in large and small vessels in a model of salt-sensitive hypertension [47].

The relationship between ET- 1 and TGF- $\beta$ is complex: ET-1 stimulates TGF- $\beta$ synthesis [48], and in turn TGF- $\beta$ augments ET- 1 expression as part of a positive feedback cycle [49]. In contrast to results of others [50], in our study $\mathrm{ET}_{\mathrm{A}}-\mathrm{RB}$ reduced TGF- $\beta$ mRNA expression as potently as the ACE-i. The combination of the two interventions provided no further benefit. Diabetes was associated with increased TGF- 
$\beta$ mRNA expression. Such overexpression was reduced by $\mathrm{ET}_{\mathrm{A}}-\mathrm{RB}$ and by $\mathrm{ACE}-\mathrm{i}$. This finding confirms that ET- 1 increases TGF- $\beta$, at least in this mod$\mathrm{el}$, and this could be one mechanism causing the increase in interstitial tissue and arterial wall thickness. On the other hand ET-1 mRNA was increased in diabetic rats and this increase was only prevented by combination treatment.

The modification of extracellular matrix components by advanced glycation leads to increased collagen cross linking and increased myocardial stiffness in diabetes [31]. In addition our study showed increased expression for collagen IV in diabetic rats. All interventions reduced its expression, but ACE-i and combination treatment were more effective than the $\mathrm{ET}_{\mathrm{A}^{-}}$ RB.

In conclusion, this study identifies a myocardial capillary deficit in diabetes. Furthermore, treatment with ACE-i was more effective than blockade of the ET-system in preventing interstitial fibrosis and capillary defect of the heart in diabetic rats. This observation documents a major pathophysiological role of the RAS in the pathogenesis of the cardiac abnormality, but the ET system seems to play a certain role in the genesis of diabetic vessel disease.

Acknowledgements. M.L. Gro $\beta$ was recipient of a grant in the Graduiertenkolleg "Nieren- und Kreislaufregulation" of the Deutsche Forschungsgemeinschaft (DFG). The study was supported by grants of the Deutsche Diabetesstiftung and the University of Heidelberg (Juniorprojects No. 83/97 and 133/00). The skillful technical assistance of Z. Antoni, P. Rieger and H. Ziebart is gratefully acknowledged. Special thanks to H. Derks and U. Burkhardt for organising the photographs and the layout.

\section{References}

1. Fein FS, Sonnenblick EH (1994) Diabetic cardiomyopathy. Cardiovasc Drugs Ther 8:65-73

2. Fischer M, Wiest G, Tekesin I et al. (1992) Effects of combined renovascular hypertension and diabetes mellitus on myocardial cells, non-vascular interstitium and capillaries: a stereological study on rat hearts. Virchows Arch A Pathol Anat Histopathol 420:499-506

3. Standl E, Schnell O, Balletshofer B et al. (1997) Influence of diabetes mellitus on the heart and macrovascular mortality. Diabetologia 40 [Suppl 2]:S125-S126

4. Suzuki T, Kumazaki T, Mitsui Y (1993) Endothelin-1 is produced and secreted by neonatal rat cardiac myocytes in vitro. Biochem Biophys Res Commun 191:823-830

5. Chua BH, Chua CC, Diglio CA, Siu BB (1998) Regulation of endothelin-1 mRNA by angiotensin II in rat heart endothelial cells. Biochim Biophys Acta 1178:201-206

6. Fukuchi M, Giaid A (1998) Expression of endothelin-1 and endothelin-converting enzyme-1 mRNAs and proteins in failing human hearts. J Cardiovasc Pharmacol 31 [Suppl 1]:S421-S423

7. Haynes WG, Ferro CJ, Webb DJ (1998) Bosentan in essential hypertension. N Engl J Med 339:346-347

8. Haynes WG, Webb DJ (1998) Endothelin as a regulator of cardiovascular function in health and disease. $\mathrm{J}$ Hypertens 16:1081-1098
9. Rabelink TJ, Stroes ES, Bouter KP, Morrison P (1998) Endothelin blockers and renal protection: a new strategy to prevent end-organ damage in cardiovascular disease? Cardiovasc Res 39:543-549

10. Rabelink TJ, Bakris GL (1998) The renin-angiotensin system in diabetic nephropathy: the endothelial connection. Miner Electrolyte Metab 24:381-388

11. Disashi T, Nonoguchi H, Iwaoka T et al. (1997) Endothelin converting enzyme-1 gene expression in the kidney of spontaneously hypertensive rats. Hypertension 30:1591-1597

12. Verhaar MC, Strachan FE, Newby DE et al. (1998) Endothelin-A receptor antagonist-mediated vasodilatation is attenuated by inhibition of nitric oxide synthesis and by endothelin-B receptor blockade. Circulation 97:752-756

13. Serneri GG, Cecioni I, Vanni S et al. (2000) Selective upregulation of cardiac endothelin system in patients with ischemic but not idiopathic dilated cardiomyopathy: endothelin1 system in the human failing heart. Circ Res 86:377-385

14. Takahashi K, Ghatei MA, Lam HC, O'Halloran DJ, Bloom SR (1999) Elevated plasma endothelin in patients with diabetes mellitus. Diabetologia 33:306-310

15. Misurski DA, Hopfner RL, McNeill JR, Gopalakrishnan V (1999) Endothelium-dependent alterations in responses of the mesenteric vascular bed in the streptozotocin diabetic rat. Proc West Pharmacol Soc 42:49-51

16. Ficai S, Herizi A, Mimran A, Jover B (2001) Endothelin blockade in angiotensin II hypertension: prevention and treatment studies in the rat. Clin Exp Pharmacol Physiol 28:1100-1103

17. Gurbanov K, Rubinstein I, Hoffman A, Abassi Z, Better OS, Winaver J (1996) Bosentan improves renal regional blood flow in rats with experimental congestive heart failure. Eur J Pharmacol 310:193-196

18. Marin-Garcia J, Goldenthal MJ, Moe GW (2002) Selective endothelin receptor blockade reverses mitochondrial dysfunction in canine heart failure. J Card Fail 8:326-332

19. Nabokov AV, Amann K, Wessels S, Munter K, Wagner J, Ritz E (1999) Endothelin receptor antagonists influence cardiovascular morphology in uremic rats. Kidney Int 55: 512-519

20. Oie E, Clausen OP, Yndestad A, Grogaard HK, Attramadal H, Oie E (2002) Endothelin receptor antagonism attenuates cardiomyocyte apoptosis after induction of ischemia in rats. Scand Cardiovasc J 36:108-116

21. Amann K, Wolf B, Nichols C (1997) Aortic changes in experimental renal failure: hyperplasia or hypertrophy of smooth muscle cells? Hypertension 29:770-775

22. Amann K, Munter K, Wessels S (2000) Endothelin A receptor blockade prevents capillary/myocyte mismatch in the heart of uremic animals. J Am Soc Nephrol 11:17021711

23. Henquell L, Odoroff CL, Honig CR (1997) Intercapillary distance and capillary reserve in hypertrophied rat hearts beating in situ. Circ Res 41:400-408

24. Buzello M, Boehm C, Orth S (2003) Myocyte loss in early left ventricular hypertrophy of experimental renovascular hypertension. Virchows Arch 442:364-371

25. Rodriguez-Porcel M, Lerman A, Ritman EL, Wilson SH, Best PJ, Lerman LO (2000) Altered myocardial microvascular 3D architecture in experimental hypercholesterolemia. Circulation 102:2028-2030

26. Kirchengast M, Munter K (1999) Endothelin-1 and endothelin receptor antagonists in cardiovascular remodeling. Proc Soc Exp Biol Med 221:312-325

27. Weber KT, Anversa P, Armstrong PW et al. (1992) Remodeling and reparation of the cardiovascular system. J Am Coll Cardiol 20:3-16 
28. Weber KT, Brilla CG, Campbell SE, Guarda E, Zhou G, Sriram K (1993) Myocardial fibrosis: role of angiotensin II and aldosterone. Basic Res Cardiol 88 [Suppl 1]:107-124

29. Weber KT, Brilla CG (1993) Structural basis for pathologic left ventricular hypertrophy. Clin Cardiol 16:II10-II14

30. Riva E, Andreoni G, Bianchi R (1998) Changes in diastolic function and collagen content in normotensive and hypertensive rats with long-term streptozotocin-induced diabetes. Pharmacol Res 37:233-240

31. Candido R, Forbes JM, Thomas MC et al. (2003) A breaker of advanced glycation end products attenuates diabetes-induced myocardial structural changes. Circ Res 92:785-792

32. Ayaz M, Can B, Ozdemir S, Turan B (2002) Protective effect of selenium treatment on diabetes-induced myocardial structural alterations. Biol Trace Elem Res 89:215-226

33. Dhein S, Hochreuther S, Aus Dem Spring C, Bollig K, Hufnagel C, Raschack M (2000) Long-term effects of the endothelin(A) receptor antagonist LU 135252 and the angiotensin-converting enzyme inhibitor trandolapril on diabetic angiopathy and nephropathy in a chronic type I diabetes mellitus rat model. J Pharmacol Exp Ther 293:351359

34. Cavasin MA, Carretero OA, Yang F, Oja-Tebbe N, Peng H, Yang XP (2002) Long-term effects of selective and nonselective endothelin receptor antagonists in mice with heart failure. J Card Fail 8:254-261

35. Basso C, Thiene G, Della Barbera M, Angelini A, Kirchengast M, Iliceto S (2002) Endothelin A-receptor antagonist administration immediately after experimental myocardial infarction with reperfusion does not affect scar healing in dogs. Cardiovasc Res 55:113-121

36. Mathiesen ER, Borch-Johnsen K, Jensen DV, Deckert T (1989) Improved survival in patients with diabetic nephropathy. Diabetologia 32:884-886

37. Hong SW, Isono M, Chen S, Iglesias-De La Cruz MC, Han DC, Ziyadeh FN (2001) Increased glomerular and tubular expression of transforming growth factor-beta1, its type II receptor, and activation of the Smad signaling pathway in the $\mathrm{db} / \mathrm{db}$ mouse. Am J Pathol 158:1653-1663

38. Woods LL, Mizelle HL, Hall JE (1987) Control of renal hemodynamics in hyperglycemia: possible role of tubuloglomerular feedback. Am J Physiol 252:F65-F73

39. Cai L, Li W, Wang G, Guo L, Jiang Y, Kang YJ (2002) Hyperglycemia-induced apoptosis in mouse myocardium: mitochondrial cytochrome C-mediated caspase-3 activation pathway. Diabetes 51:1938-1948

40. Benigni A, Colosio V, Brena C, Bruzzi I, Bertani T, Remuzzi G (1998) Unselective inhibition of endothelin receptors reduces renal dysfunction in experimental diabetes. Diabetes 47:450-456

41. Nabokov A, Amann K, Wagner J, Gehlen F, Munter K, Ritz E (1996) Influence of specific and non-specific endothelin receptor antagonists on renal morphology in rats with surgical renal ablation. Nephrol Dial Transplant 11:514-520

42. Witte K, Reitenbach I, Stolpe K, Schilling L, Kirchengast M, Lemmer B (2003) Effects of the endothelin a receptor antagonist darusentan on blood pressure and vascular contractility in type 2 diabetic Goto-Kakizaki rats. J Cardiovasc Pharmacol 41:890-896

43. Verma S, Maitland A, Weisel RD et al. (2002) Hyperglycemia exaggerates ischemia-reperfusion-induced cardiomyocyte injury: reversal with endothelin antagonism. J Thorac Cardiovasc Surg 123:1120-1124

44. Vesci L, Mattera GG, Tobia P, Corsico N, Calvani M (1995) Cardiac and renal endothelin-1 binding sites in streptozotocin-induced diabetic rats. Pharmacol Res 32:363-367

45. Crespo MJ, Moreta S, Gonzalez J (2003) Cardiovascular deterioration in STZ-diabetic rats: possible role of vascular RAS. Pharmacology 68:1-8

46. Fiordaliso F, Li B, Latini R (2000) Myocyte death in streptozotocin-induced diabetes in rats in angiotensin II-dependent. Lab Invest 80:513-527

47. Park JB, Schiffrin EL (2001) ET(A) receptor antagonist prevents blood pressure elevation and vascular remodeling in aldosterone-infused rats. Hypertension 37:1444-1449

48. Zoja C, Orisio S, Perico N (1991) Constitutive expression of endothelin gene in cultured human mesangial cells and its modulation by transforming growth factor-beta, thrombin, and a thromboxane A2 analogue. Lab Invest 64:16-20

49. Kurihara H, Yoshizumi M, Sugiyama T et al. (1998) Transforming growth factor-beta stimulates the expression of endothelin mRNA by vascular endothelial cells. Biochem Biophys Res Commun 159:1435-1440

50. Gilbert RE, Rumble JR, Cao Z (2000) Endothelin receptor antagonism ameliorates mast cell infiltration, vascular hypertrophy, and epidermal growth factor expression in experimental diabetes. Circ Res 86:158-165 